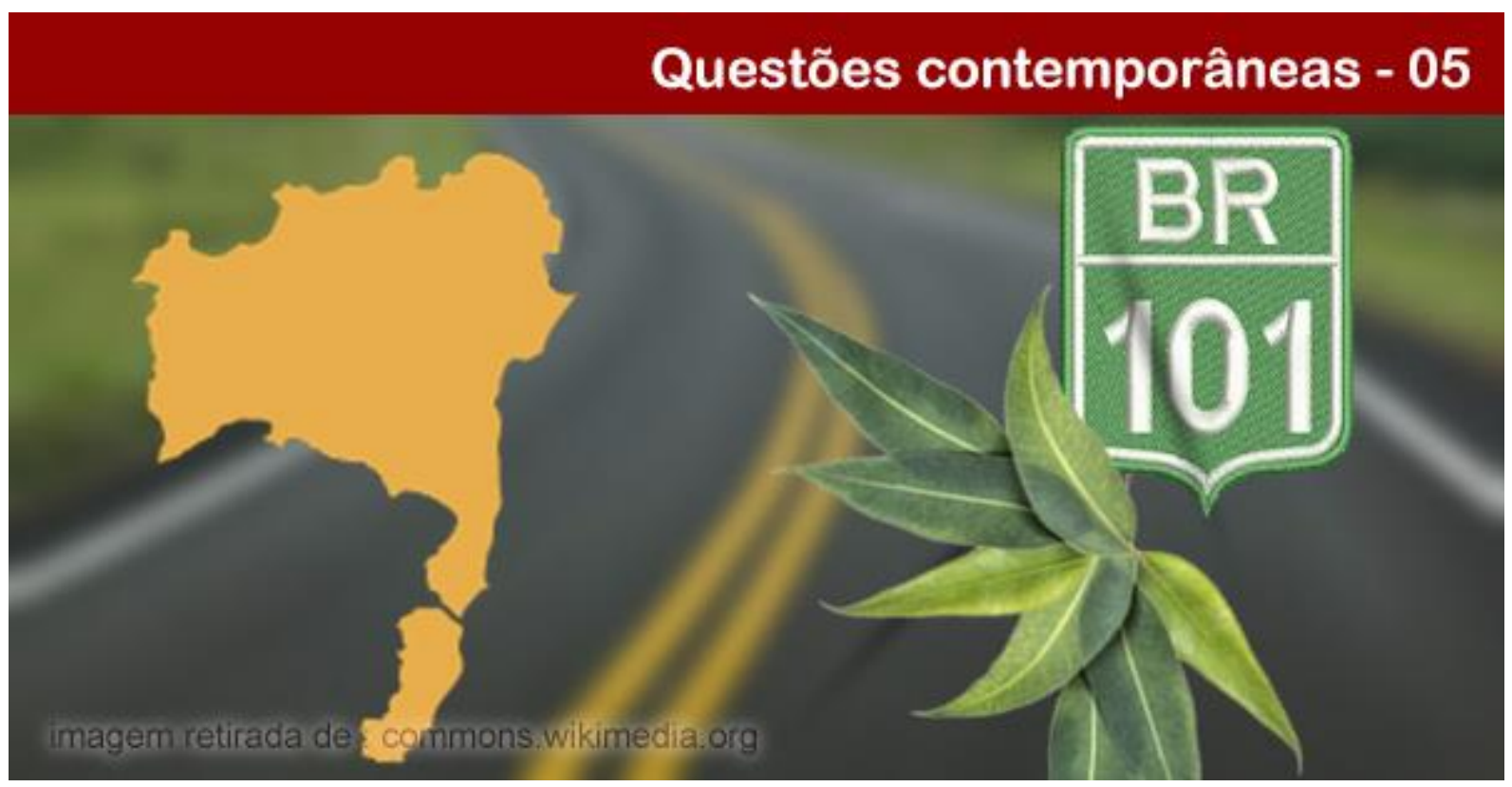

\title{
EXPANSÃO DA MONOCULTURA DE EUCALIPTO DAS INDÚSTRIAS DE PAPEL E CELULOSE: UMA ARENA DE CONFLITOS AMBIENTAIS
}

\author{
Rodney Alves Barbosa \\ Professor efetivo do Instituto Federal de Minas Gerais (IFMG/SJE). Doutorando em Extensão Rural na \\ Universidade Federal de Viçosa (UFV). Mestre em Engenharia de Produção pela Universidade Federal de Santa \\ Catarina (UFSC). Licenciado em Matemática pela Faculdade de Filosofia Ciências e Letras do Alto São \\ Francisco(FASF). E-mail: rodney.barbosa@ifmg.edu.br.
}

\section{Marcelo Leles Romarco de Oliveira}

Professor adjunto IV do Departamento de Economia Rural e do Programa de Pós-Graduação em Extensão Rural da Universidade Federal de Viçosa (UFV). Doutor em Ciências Sociais pela Universidade Federal Rural do Rio de Janeiro (CPDA/UFRRJ). Mestre em Extensão Rural pela UFV. Graduado em Administração pela Universidade Federal de Lavras (UFLA). E-mail: marceloromarco@gmail.com.

\section{Katia de Fatima Vilela}

Professora efetiva do Instituto Federal de Minas Gerais (IFMG/SJE). Doutoranda em Extensão Rural na Universidade Federal de Viçosa (UFV). Mestre em Gestão Social, Educação e Desenvolvimento Regional pela Faculdade Vale do Cricaré (FVC). Graduada em Administração pela Faculdade do Sul da Bahia (FASB). E-mail: katia.vilela@ifmg.edu.br.

\section{Mariane Batalha Roque}

Doutoranda e mestre em Extensão Rural pela Universidade Federal de Viçosa (UFV). Graduada em Geografia pela UFV. E-mail: marianepr.batalha@gmail.com.

Resumo: Com a construção da rodovia BR101, no final da década de 1960, ligando os estados do Espírito Santo e Bahia, a região passou por um intenso processo de exploração da madeira nativa, seguida da ocupação por pastagens destinadas à criação de gado, até chegar aos cultivos de eucalipto, para produção de papel e celulose. O objetivo deste trabalho é apresentar os conflitos ambientais provocados pela monocultura do eucalipto, no norte do Espírito Santo e no sul da Bahia, e fazer uma reflexão sobre os problemas ocasionados pela introdução da monocultura do eucalipto para atender ao setor de celulose. Este artigo traz uma revisão bibliográfica que analisa os trabalhos de Henri Acselrad e do Observatório Social, que discutem as questões conflituosas provocadas pelo

\section{POLÊM!CA $\mid$ LABORE (}

Polêmica - Revista Eletrônica da Uerj - Rua São Francisco Xavier, 524, $1^{\circ}$ andar bloco D, sl.1001 • Tels.: +55 21 2334-4088 / 4087 • http://www.e-publicacoes.uerj.br/index.php/polemica/index http://www.labore.uerj.br • laboreuerj@yahoo.com.br 
avanço da monocultura do eucalipto em comunidades quilombolas e indígenas daquela região, como também faz uma análise dos documentos disponibilizados pelas empresas de celulose que atuam nos dois estados. Os conflitos das comunidades com as empresas de celulose destacam-se tanto pela ocupação do solo, como pelo avanço da monocultura do eucalipto sobre as comunidades, realidade que tem provocado resistência desses grupos, diante da expansão da atividade naquela região.

Palavras-chave: Observatório social. Quilombolas. Espírito Santo. Bahia.

\title{
EXPANSION OF EUCALYPTUS MONOCULTURE OF PAPER AND CELLULOSE INDUSTRIES: AN ARENA OF ENVIRONMENTAL CONFLICTS
}

\begin{abstract}
The construction of the BR101 highway in the late 1960s, connecting the Brazilian States of Espírito Santo (ES) and Bahia (BA), culminated in an intense process of exploration of native wood in the region, followed by pasture areas, which were later substituted by eucalyptus plantations for cellulose and paper production. The objective of this study is to present the environmental conflicts caused by the eucalyptus monoculture in the north of ES and south of BA states. There is also a consideration about the problems caused by the introduction of eucalyptus monoculture in this area, to provide the cellulose sector. This study presents a bibliographical review that analyzes the studies of Henri Acselrad and the Social Observatory which discuss the issues caused by the advance of eucalyptus monoculture in quilombola and indigenous communities in the same area of the present study. Both also make analyses of the documents provided by the cellulose companies' operating in this area. The conflicts between the communities and the companies involve the occupation of the soil, as well as the advance of the eucalyptus monoculture over the communities' land, a reality that has triggered resistance movements from these groups in the face of the expansion of the industries' activity in the region.
\end{abstract}

Keywords: Social observatory. Quilombolas. Espirito Santo. Bahia.

\section{Introdução}

O desenvolvimento das práticas agrícolas, ao longo dos séculos, deu origem às novas e diversificadas formas de produção, o que resultou na especialização produtiva, seja de commodities, como a soja e o milho, seja de outros produtos de origem florestal ou animal, como a celulose ou a carne. A opção por esse modelo de produção, caracterizado por um padrão monocultor e intensivo no uso de insumos e de mecanização, fomentou a formação dos chamados complexos agroindustriais e causou uma série de impactos sociais e ambientais.

No Brasil, esse padrão de produção tem impactado o modo de vida de diversos grupos sociais do campo, entre eles as comunidades quilombolas e indígenas. A esse respeito, no norte do Espírito Santo e no sul da Bahia tem se destacado a monocultura de eucalipto, pelas profundas transformações que vem causando no território para sua implantação. Diversos estudos sobre seus impactos na vida desses grupos têm sido realizados, podendo-se destacar os trabalhos empíricos de Henri Acselrad, em 2007, e do Observatório Social, em 2012, que registraram e analisaram os conflitos entre as comunidades quilombolas e indígenas e as empresas do setor de celulose, na referida região.

Esses conflitos são classificados como socioambientais, pois podem ser entendidos como sendo aqueles que envolvem grupos sociais com modo de vida diferenciado de apropriação, uso e significação do território. Os conflitos socioambientais configuram-se de

\section{POLÊM!CA $\mid$ LABORE}

Polêmica - Revista Eletrônica da Uerj - Rua São Francisco Xavier, 524, $1^{\circ}$ andar

bloco D, sl.1001 • Tels.: +55 21 2334-4088 / 4087 • http://www.e-publicacoes.uerj.br/index.php/polemica/index http://www.labore.uerj.br • laboreuerj@yahoo.com.br 
forma implícita ou explícita, com foco e disputa em elementos da natureza e com relações de tensões sociais entre interesses coletivos e privados, gerados pela apropriação de espaços ou de recursos coletivos por diferentes atores sociais, para atender a interesses pessoais (SCOTTO, 1997; ACSELRAD, 2004; LITTLE, 2004).

Entre as regiões do norte do Espírito Santo e sul da Bahia, existem 34 comunidades quilombolas, além de aldeias indígenas (ACSELRAD, 2007). Nelas, há também três grandes empresas do setor de papel e celulose: Fibria Aracruz, Veracel Celulose e Suzano Papel e Celulose. Ali, foi formado um cenário de conflito e disputa por território, o que será explorado no presente artigo, além da relação das empresas do setor de celulose com as comunidades quilombolas e indígenas que vivem e trabalham naquela região. Para isso, a pesquisa se baseou nos trabalhos de Henri Acselrad e do Observatório Social realizados nas regiões norte do Espírito Santo e sul da Bahia, bem como em documentos disponibilizados pelas três empresas de celulose dessas regiões. Para classificar e quantificar as áreas de formação florestal do Bioma da Mata Atlântica e das áreas de floresta plantada, que categorizam a silvicultura foram utilizados os dados disponibilizados pelo Projeto MapBiomas. Assim, foi possível compreender a origem dos conflitos gerados pelas extensas áreas destinadas ao cultivo do eucalipto para abastecimento das fábricas de celulose. Os impactos da monocultura do eucalipto são registrados a partir das entrevistas do Observatório Social realizadas com moradores das comunidades quilombolas e indígenas afetadas. Neste artigo, esses moradores serão tratados pelas iniciais de seus nomes: AC, MT, PL, LS e EJ.

\section{Um breve debate sobre as transformações da agricultura brasileira}

O Brasil sempre foi um espaço de apropriação desigual do seu território. A lógica colonialista de acumulação de riqueza e expropriação das terras dos povos que aqui viviam foi predominante, seja pela exploração das riquezas minerais, seja pelos grandes monocultivos inaugurados no País, a partir do século XVI. Pode-se citar como exemplo a cana-de-açúcar para fabricação e exportação do açúcar em larga escala para países da Europa. Posteriormente, outras culturas, como o cacau e o café, somaram-se a esse cenário e contribuíram para a consolidação desse modelo agrícola concentrador.

A Lei Senador Vergueiro, ou simplesmente Lei de Terras de 1850, garantiu a apropriação mercantil do espaço agrário brasileiro, passando do regime de concessão e

\section{POLÊM!CA $\mid$ LABORE}

Polêmica - Revista Eletrônica da Uerj - Rua São Francisco Xavier, 524, $1^{\circ}$ andar

bloco D, sl.1001 • Tels.: +55 21 2334-4088 / 4087 • http://www.e-publicacoes.uerj.br/index.php/polemica/index

http://www.labore.uerj.br • laboreuerj@yahoo.com.br 
sesmarias e transformando a terra em uma mercadoria que poderia ser comprada e vendida, deixando de fora, portanto, uma massa de posseiros, populações nativas e outros trabalhadores que viviam nesses espaços (STÉDILE; ESTEVAM, 2013).

Esse cenário contribuiu para que fossem garantidas as bases para o aprofundamento das desigualdades no campo e, consequentemente, o acirramento de conflitos pela luta e posse da terra (ANDRADE; OLIVEIRA, 2016). As próprias condições histórico-sociais que regularam a ocupação do espaço agrário brasileiro conformaram uma estrutura agrária com alta concentração fundiária, resultando em conflitos e resistências por parte de diversos povos e segmentos organizados do campo (GERMANI, 2006).

Os conflitos começaram a se acirrar, principalmente, a partir da transformação da agricultura, que pode ser entendida como uma passagem do que se chamou complexo rural para os complexos agroindustriais, também conhecidos como agronegócio, aproximando a indústria do campo (KAGEYAMA, 1990; CAMACHO, 2012). O agronegócio é um complicado sistema que engloba a agricultura, a indústria, o comércio e o mercado financeiro, e estava naturalmente envolvido em conflitos por território, na forma de encurralamentos, de resistências e de reapropriações de terras comunitárias (em geral devolutas), que se transformaram em monoculturas (CAMACHO, 2012).

O processo histórico de transformação da agricultura proporcionou mudanças na estruturação social, e isto pode ser considerado como um dos cernes dos conflitos no campo brasileiro. O agronegócio, por sua vez, tem contribuído para expansão dos conflitos, pois controla as relações sociais e o domínio territorial (MARTINS, 2004; FERNANDES, 2005).

\section{O setor de papel e celulose e a monocultura do eucalipto}

A expansão dos conflitos no campo brasileiro será discutida, nesta pesquisa, sob a perspectiva das relações das comunidades tradicionais do norte do Espírito Santo e do sul da Bahia com a monocultura do eucalipto destinada ao setor de papel e celulose dessas regiões.

A implantação da monocultura do eucalipto no Brasil se deu não só pelo interesse do setor privado, mas também foi impulsionada pelos interesses do Estado brasileiro (ACSELRAD, 2007). Para implantar e incentivar a monocultura do eucalipto e de outras espécies, o Estado criou uma série de mecanismos jurídicos que fomentavam o setor florestal e apoiavam os plantios industriais destinados aos setores de celulose e siderúrgico. Inúmeros

\section{POLÊM!CA $\mid$ LABORE}

Polêmica - Revista Eletrônica da Uerj - Rua São Francisco Xavier, 524, $1^{\circ}$ andar bloco D, sl.1001 • Tels.: +55 21 2334-4088 / 4087 • http://www.e-publicacoes.uerj.br/index.php/polemica/index http://www.labore.uerj.br • laboreuerj@yahoo.com.br 
foram os investimentos diretos e indiretos, dentre os quais se destacam: i) 1965 - Lei no 4.771, do Novo Código Florestal; ii) 1966 - Lei no 5.106, de Incentivos Fiscais; iii) 1965 Criação do Instituto Brasileiro de Desenvolvimento Florestal; iv) 1970 - Decreto-Lei $\mathrm{n}^{\mathrm{o}}$ 1.134, que permite às pessoas jurídicas reinvestirem $50 \%$ do imposto de renda (IR) em empreendimentos florestais; v) 1974 - Decreto-Lei no 1.376, que cria o Fundo de Investimentos Regionais, operado pelo Banco Mundial; vi) 1974 - Decreto no 79.046 , que redesenha o setor, para ganhos em escala e produtividade; e vii) 1975 - Criação do Plano Nacional de Papel e Celulose.

Esses incentivos demonstram as ações do Estado para fomentar e consolidar o setor florestal brasileiro. Outro fator importante foi a mundialização da agricultura, que desenhou uma nova etapa do capitalismo, do final do século $\mathrm{XX}$, elevando a produção agrícola a uma escala mundial e dominada por conglomerados empresariais (OLIVEIRA, 2012; ANDRADE; OLIVEIRA, 2016).

As maiores empresas de papel e celulose foram formadas por diversas fusões, sendo esse um movimento importante no processo de reestruturação do setor, pois possibilita maior elasticidade ao deslocamento das empresas. Essa técnica de reorganização viabiliza condições para que a empresa criada na fusão busque se instalar ou ampliar as atividades em áreas com maior disponibilidade de terra e de mão de obra barata, como, por exemplo, a região analisada nesta pesquisa (ANDRADE; OLIVEIRA, 2016).

A dinâmica do setor de papel e celulose pode ser percebida nas empresas do norte do Espírito Santo e do sul da Bahia, onde, em nove anos, aconteceram as seguintes mudanças: i) a empresa Veracel Celulose, na cidade de Eunápolis, BA, sofreu fusão com a brasileira Fibria e a sueco-filandesa Stora-Enso; ii) a Bahia Sul Celulose, na cidade de Mucuri, BA, foi vendida para Suzano Papel e Celulose; e iii) a Aracruz, na cidade de Aracruz, ES, passou a ser denominada Fibria Aracruz.

A capacidade de produção dessas três fábricas está ligada diretamente à disponibilidade da sua principal matéria-prima, o eucalipto. Para abastecimento das fábricas, são necessárias extensas áreas para plantio de eucalipto, que estão distribuídas em vários municípios. As Tabelas 1, 2 e 3 apresentam os municípios onde as empresas Veracel Celulose, Suzano Papel e Celulose e Fibria Aracruz exploram o eucalipto para produção de papel e celulose, no norte do Espírito Santo e no sul da Bahia, estendendo-se para alguns municípios de Minas Gerais.

\section{POLÊM!CA $\mid$ LABORE}

Polêmica - Revista Eletrônica da Uerj - Rua São Francisco Xavier, 524, $1^{\circ}$ andar bloco D, sl.1001 • Tels.: +55 21 2334-4088 / 4087 • http://www.e-publicacoes.uerj.br/index.php/polemica/index http://www.labore.uerj.br • laboreuerj@yahoo.com.br 
Alguns munícipios dessas regiões têm mais de uma empresa do setor de papel e celulose com plantios de eucalipto na cidade.

Além dos municípios onde as empresas atuam, nas Tabelas 1, 2 e 3, também estão relacionadas as áreas de formação florestal, que fazem parte do Bioma Mata Atlântica (ROSA, 2016), e as áreas de floresta plantada, que correspondem às áreas de silvicultura das empresas privadas e dos produtores rurais. Independentemente da área de silvicultura de cada empresa, as tabelas mostram o quanto cada município possui de formação florestal e de floresta plantada.

A Tabela 1 apresenta os municípios onde a Veracel Celulose possui 83.698 ha de área plantada ou disponível para o plantio de eucalipto: Belmonte, Canavieiras, Eunápolis, Guaratinga, Itabela, Itagimirim, Itapebi, Mascote, Porto Seguro e Santa Cruz Cabrália. Sua fábrica está localizada entre os municípios de Eunápolis e Belmonte (BA) (VERACEL, 2016). Observa-se, ainda, que nessas cidades onde a empresa atua a área de floresta planta é de 95.876,570 hectares (MAPBIOMAS, 2019).

Tabela - 1: Municípios de atuação da empresa Veracel Celulose.

\begin{tabular}{|c|c|c|c|c|c|c|}
\hline \multirow[b]{2}{*}{$\begin{array}{l}\text { CIDADES ONDE A } \\
\text { VERACEL ESTÁ } \\
\text { PRESENTE } \\
\text { (VERACEL, 2016) }\end{array}$} & \multirow[b]{2}{*}{ ESTADO } & \multirow[b]{2}{*}{$\begin{array}{l}\text { Extensão } \\
\text { do } \\
\text { município } \\
(\mathrm{Km} 2)\end{array}$} & \multicolumn{2}{|c|}{2018} & \multirow[b]{2}{*}{$\begin{array}{l}\text { Percentagem de } \\
\text { Formação } \\
\text { florestal do } \\
\text { município }\end{array}$} & \multirow[b]{2}{*}{$\begin{array}{c}\text { Percentagem } \\
\text { de floresta } \\
\text { plantada do } \\
\text { município }\end{array}$} \\
\hline & & & $\begin{array}{c}\text { Área de } \\
\text { formação } \\
\text { florestal } \\
\text { (hectares) } *\end{array}$ & $\begin{array}{c}\text { Área de } \\
\text { floresta } \\
\text { plantada } \\
(\text { hectares) } *\end{array}$ & & \\
\hline BELMONTE & $\mathrm{BA}$ & $1.939,447$ & $80.963,29$ & $12.265,55$ & $41,75 \%$ & $6,32 \%$ \\
\hline CANAVIEIRAS & $\mathrm{BA}$ & $1.334,295$ & $59.358,12$ & 465,52 & $44,49 \%$ & $0,35 \%$ \\
\hline EUNÁPOLS & BA & $1.425,970$ & $25.124,05$ & $15.208,46$ & $17,62 \%$ & $10,67 \%$ \\
\hline GUARATINGA & $\mathrm{BA}$ & $2.189,404$ & $47.310,74$ & $5.066,22$ & $21,61 \%$ & $2,31 \%$ \\
\hline ITABELA & BA & 924,926 & $23.529,13$ & $7.253,43$ & $25,44 \%$ & $7,84 \%$ \\
\hline ITAGIMIRM & BA & 876,800 & $9.880,29$ & $6.561,58$ & $11,27 \%$ & $7,48 \%$ \\
\hline ITAPEBI & BA & $1.013,074$ & $27.063,50$ & $2.324,39$ & $26,71 \%$ & $2,29 \%$ \\
\hline MASCOTE & BA & 742,689 & $39.011,77$ & $2.926,25$ & $52,53 \%$ & $3,94 \%$ \\
\hline PORTO SEGURO & BA & $2.285,764$ & $78.134,70$ & $26.425,20$ & $34,18 \%$ & $11,56 \%$ \\
\hline $\begin{array}{l}\text { SANTA CRUZ } \\
\text { CABRÁLIA }\end{array}$ & BA & $1.462,942$ & $63.034,95$ & $17.379,97$ & $43,09 \%$ & $11,88 \%$ \\
\hline
\end{tabular}

Fonte: adaptada de Veracel (2016), *MapBiomas (2019).

A Tabela 2 mostra os municípios onde a empresa Suzano Papel e Celulose possui 149.816 ha de área plantada ou disponível para o plantio de eucalipto, divididos em 19 municípios, distribuídos em três estados. Em Minas Gerais, a empresa possui plantações em três municípios, sendo eles: Carlos Chargas, Nanuque e Umburatiba; no Espírito Santo em seis municípios: Conceição da Barra, Montanha, Mucurici, Pedro Canário, Pinheiros e São Mateus;

\section{POLÊM!CA $\mid$ LABORE}

Polêmica - Revista Eletrônica da Uerj - Rua São Francisco Xavier, 524, $1^{\circ}$ andar bloco D, sl.1001 • Tels.: +55 21 2334-4088 / 4087 • http://www.e-publicacoes.uerj.br/index.php/polemica/index http://www.labore.uerj.br • laboreuerj@yahoo.com.br 
e na Bahia em dez municípios: Alcobaça, Caravelas, Ibirapuã, Lajedão, Medeiros Neto, Mucuri, Nova Viçosa, Prado, Teixeira de Freitas e Vereda na Bahia (SUZANO, 2013). Sua fábrica localiza-se no município de Mucuri, BA. Nota-se que nos municípios onde a empresa atua, a área de floresta plantada corresponde a 406.411,270 hectares, haja vista que em algumas cidades há atividade florestal de outras empresas de celulose (MAPBIOMAS, 2019).

Tabela - 2: Municípios de atuação da empresa Suzano Papel e Celulose.

\begin{tabular}{|c|c|c|c|c|c|c|}
\hline \multirow[b]{2}{*}{$\begin{array}{l}\text { CIDADES ONDE } \\
\text { SUZANO ESTÁ } \\
\text { PRESENTE } \\
\text { (SUZANO, 2013) }\end{array}$} & \multirow[b]{2}{*}{ ESTADO } & \multirow[b]{2}{*}{$\begin{array}{l}\text { Extensão } \\
\text { do } \\
\text { município } \\
\left(\mathrm{km}^{2}\right)\end{array}$} & \multicolumn{2}{|c|}{2018} & \multirow[b]{2}{*}{$\begin{array}{l}\text { Percentagem de } \\
\text { Formação } \\
\text { florestal do } \\
\text { município }\end{array}$} & \multirow[b]{2}{*}{$\begin{array}{c}\text { Percentagem } \\
\text { de floresta } \\
\text { plantada do } \\
\text { município }\end{array}$} \\
\hline & & & $\begin{array}{c}\text { Área de } \\
\text { formação } \\
\text { florestal } \\
\text { (hectares) * }\end{array}$ & $\begin{array}{c}\text { Área de } \\
\text { floresta } \\
\text { plantada } \\
\text { (hectares) } *\end{array}$ & & \\
\hline ALCOBAÇA & BA & $1.482,285$ & $63.689,57$ & $16.847,69$ & $42,97 \%$ & $11,37 \%$ \\
\hline CARAVELAS & BA & $2.377,87$ & $96.894,63$ & $19.898,09$ & $40,75 \%$ & $8,37 \%$ \\
\hline IBIRAPUÃ & BA & 771,098 & $5.612,91$ & $12.153,04$ & $7,28 \%$ & $15,76 \%$ \\
\hline \multirow{2}{*}{$\begin{array}{l}\text { LAJEDÃO } \\
\text { MEDEIROS } \\
\text { NETO }\end{array}$} & BA & 624,353 & 540,24 & $4.536,65$ & $0,87 \%$ & $7,27 \%$ \\
\hline & BA & $1.311,74$ & $2.479,48$ & $4.608,81$ & $1,89 \%$ & $3,51 \%$ \\
\hline MUCURI & BA & $1.787,626$ & $20.206,21$ & $78.825,58$ & $11,30 \%$ & $44,10 \%$ \\
\hline NOVA VIÇOSA & BA & $1.316,380$ & $13.006,94$ & $70.277,98$ & $9,88 \%$ & $53,39 \%$ \\
\hline $\begin{array}{l}\text { PRADO } \\
\text { TEXEIRA DE }\end{array}$ & BA & $1.687,833$ & $45.485,09$ & $24.830,54$ & $26,95 \%$ & $14,71 \%$ \\
\hline FREITAS & BA & $1.165,622$ & $7.882,86$ & $18.044,26$ & $6,76 \%$ & $15,48 \%$ \\
\hline \multirow{2}{*}{$\begin{array}{l}\text { VEREDA } \\
\text { CONCEIÇÃO DA } \\
\text { BARRA }\end{array}$} & BA & 782,141 & $8.898,74$ & $3.865,30$ & $11,38 \%$ & $4,94 \%$ \\
\hline & $\mathrm{ES}$ & $1.182,587$ & $11.159,64$ & $61.344,01$ & $9,44 \%$ & $51,87 \%$ \\
\hline MONTANHA & $\mathrm{ES}$ & $1.099,060$ & $4.247,57$ & $5.892,08$ & $3,86 \%$ & $5,36 \%$ \\
\hline \multirow{2}{*}{$\begin{array}{l}\text { MUCURICI } \\
\text { PEDRO } \\
\text { CANÁRIO }\end{array}$} & ES & 540,529 & 947,79 & $3.112,23$ & $1,75 \%$ & $5,76 \%$ \\
\hline & $\mathrm{ES}$ & 433,453 & $1.545,78$ & $4.463,68$ & $3,57 \%$ & $10,30 \%$ \\
\hline PINHEIROS & $\mathrm{ES}$ & 973,136 & $5.782,37$ & $4.970,00$ & $5,94 \%$ & $5,11 \%$ \\
\hline \multirow{2}{*}{$\begin{array}{l}\text { SÃO MATE } \\
\text { CARLOS } \\
\text { CHAGAS }\end{array}$} & $\mathrm{ES}$ & $2.346,047$ & $22.157,51$ & $53.922,02$ & $9,44 \%$ & $22,98 \%$ \\
\hline & MG & $3.202,984$ & $20.182,75$ & $8.352,57$ & $6,30 \%$ & $2,61 \%$ \\
\hline NANUQUE & MG & $1.518,166$ & $4.488,54$ & $8.506,62$ & $2,96 \%$ & $5,60 \%$ \\
\hline UMBURATIBA & MG & 405,834 & $3.012,48$ & $1.960,12$ & $7,42 \%$ & $4,83 \%$ \\
\hline
\end{tabular}

Fonte: adaptada da Suzano (2013), *MapBiomas (2019).

A Tabela 3 apresenta os municípios onde a Fibria Aracruz desenvolve a atividade florestal, sendo proprietária de 210.932 ha de área plantada ou disponível para o plantio de eucalipto, divididos em 27 municípios, abrangendo três estados, sendo oito na Bahia: Alcobaça, Caravelas, Ibirapuã, Mucuri, Nova Viçosa, Prado, Teixeira de Freitas e Vereda; três em Minas

\section{POLÊM!CA $\mid$ LABORE}

Polêmica - Revista Eletrônica da Uerj - Rua São Francisco Xavier, 524, $1^{\circ}$ andar bloco D, sl.1001 • Tels.: +55 21 2334-4088 / 4087 • http://www.e-publicacoes.uerj.br/index.php/polemica/index http://www.labore.uerj.br • laboreuerj@yahoo.com.br 
Gerais: Carlos Chagas, Frei Inocêncio e Nanuque; e 16 no Espírito Santo: Aracruz, Conceição da Barra, Ecoporanga, Fundão, Ibatiba, Jaguaré, Linhares, Montanha, Mucurici, Pinheiros, Ponto Belo, Rio Bananal, Serra, Sooretama, São Mateus e Vila Valério (FIBRIA, 2017). Sua fábrica está instalada na cidade de Aracruz, ES.

Nessas cidades onde a empresa atua, a área de floresta plantada é de 454.770,650 hectares, devendo ser ressaltado que outras empresas também atuam em algumas dessas cidades, como é o caso de Conceição da Barra, Mucurici, Pinheiros, São Mateus, Alcobaça, Ibirapuã, Mucuri, Nova Viçosa, Prado, Teixeira de Freitas, Vereda, Carlos Chagas e Nanuque. Observa-se, ainda, que em determinados municípios a floresta plantada representa mais de $40 \%$ e, em outros, a área de formação florestal está abaixo de $10 \%$ da extensão do município (MAPBIOMAS, 2019).

Tabela - 3: Municípios de atuação da empresa Fibria Aracruz.

\begin{tabular}{|c|c|c|c|c|c|c|}
\hline \multirow[b]{2}{*}{$\begin{array}{l}\text { CIDADES ONDE } \\
\text { ARACRUZ ESTÁ } \\
\text { PRESENTE } \\
\text { (ARACRUZ, 2017) }\end{array}$} & \multirow[b]{2}{*}{ ESTADO } & \multirow[b]{2}{*}{$\begin{array}{l}\text { Extensão } \\
\text { do } \\
\text { município } \\
\left(\mathrm{km}^{2}\right)\end{array}$} & \multicolumn{2}{|c|}{2018} & \multirow[b]{2}{*}{$\begin{array}{c}\text { Percentagem de } \\
\text { Formação } \\
\text { florestal do } \\
\text { município }\end{array}$} & \multirow[b]{2}{*}{$\begin{array}{c}\text { Percentagem } \\
\text { de floresta } \\
\text { plantada do } \\
\text { município }\end{array}$} \\
\hline & & & $\begin{array}{c}\text { Área de } \\
\text { formação } \\
\text { florestal } \\
\text { (hectares)* }\end{array}$ & $\begin{array}{c}\text { Área de } \\
\text { floresta } \\
\text { plantada } \\
\text { (hectares)* }\end{array}$ & & \\
\hline $\begin{array}{l}\text { ARACRUZ } \\
\text { CONCEIÇÃO DA }\end{array}$ & $\mathrm{ES}$ & $1.420,285$ & $26.177,24$ & $40.573,76$ & $18,43 \%$ & $28,57 \%$ \\
\hline BARRA & $\mathrm{ES}$ & $1.182,587$ & $11.159,64$ & $61.344,01$ & $9,44 \%$ & $51,87 \%$ \\
\hline ECOPORANGA & $\mathrm{ES}$ & $2.285,369$ & $8.118,19$ & $1.163,78$ & $3,55 \%$ & $0,51 \%$ \\
\hline FUNDÃO & ES & 286,854 & $7.176,12$ & $1.405,21$ & $25,02 \%$ & $4,90 \%$ \\
\hline IBATIBA & ES & 240,278 & $4.106,33$ & 665,49 & $17,09 \%$ & $2,77 \%$ \\
\hline JAGUARÉ & ES & 659,751 & $9.748,84$ & $7.412,69$ & $14,78 \%$ & $11,24 \%$ \\
\hline LINHARES & $\mathrm{ES}$ & $3.496,263$ & $75.708,22$ & $19.345,93$ & $21,65 \%$ & $5,53 \%$ \\
\hline MONTANHA & $\mathrm{ES}$ & $1.099,060$ & $4.247,57$ & $5.892,08$ & $3,86 \%$ & $5,36 \%$ \\
\hline MUCURICI & ES & 540,529 & 947,79 & $3.112,23$ & $1,75 \%$ & $5,76 \%$ \\
\hline PINHEIROS & ES & 973,136 & $5.782,37$ & $4.970,00$ & $5,94 \%$ & $5,11 \%$ \\
\hline PONTO BELO & ES & 360,110 & 504,30 & $\begin{array}{c}\text { Não } \\
\text { observado }\end{array}$ & $1,40 \%$ & $\begin{array}{c}\text { Não } \\
\text { observado }\end{array}$ \\
\hline RIO BANANAL & $\mathrm{ES}$ & 641,929 & $11.607,56$ & $3.619,39$ & $18,08 \%$ & $5,64 \%$ \\
\hline SERRA & ES & 547,631 & $11.126,56$ & $2.484,93$ & $20,32 \%$ & $4,54 \%$ \\
\hline SOORETAMA & ES & 587,036 & $26.321,15$ & $3.978,64$ & $44,84 \%$ & $6,78 \%$ \\
\hline SÃO MATEUS & ES & $2.346,047$ & $22.157,51$ & $53.922,02$ & $9,44 \%$ & $22,98 \%$ \\
\hline VILA VALÉRIO & ES & 470,343 & $6.471,98$ & $3.011,41$ & $13,76 \%$ & $6,40 \%$ \\
\hline ALCOBAÇA & BA & $1.482,285$ & $63.689,57$ & $16.847,69$ & $42,97 \%$ & $11,37 \%$ \\
\hline IBIRAPUÃ & BA & 771,098 & $5.612,91$ & $12.153,04$ & $7,28 \%$ & $15,76 \%$ \\
\hline MUCURI & BA & $1.787,626$ & $20.206,21$ & $78.825,58$ & $11,30 \%$ & $44,10 \%$ \\
\hline NOVA VIÇOSA & BA & $1.316,380$ & $13.006,94$ & $70.277,98$ & $9,88 \%$ & $53,39 \%$ \\
\hline
\end{tabular}

\section{POLÊM!CA LABORE}

Polêmica - Revista Eletrônica da Uerj - Rua São Francisco Xavier, 524, $1^{\circ}$ andar bloco D, sl.1001 • Tels.: +55 21 2334-4088 / 4087 • http://www.e-publicacoes.uerj.br/index.php/polemica/index http://www.labore.uerj.br • laboreuerj@yahoo.com.br 


\begin{tabular}{|c|c|c|c|c|c|c|}
\hline PRADO & $\mathrm{BA}$ & $1.687,833$ & $45.485,09$ & $24.830,54$ & $26,95 \%$ & $14,71 \%$ \\
\hline $\begin{array}{l}\text { TEIXEIRA DE } \\
\text { FREITAS }\end{array}$ & $\mathrm{BA}$ & $1.165,622$ & $7.882,86$ & $18.044,26$ & $6,76 \%$ & $15,48 \%$ \\
\hline VEREDA & $\mathrm{BA}$ & 782,141 & $8.898,74$ & $3.865,30$ & $11,38 \%$ & $4,94 \%$ \\
\hline CARLOS CHAGAS & MG & $3.202,984$ & $20.182,75$ & $8.352,57$ & $6,30 \%$ & $2,61 \%$ \\
\hline FREI INOCÊNCIO & MG & 469,557 & $1.511,42$ & 165,50 & $3,22 \%$ & $0,35 \%$ \\
\hline NANUQUE & MG & $1.518,166$ & $4.488,54$ & $8.506,62$ & $2,96 \%$ & $5,60 \%$ \\
\hline
\end{tabular}

Fonte: adaptada de Fibria (2017), *MapBiomas (2019).

Nas Tabelas 1, 2 e 3, constata-se que 444.446 ha são das empresas e estão plantados ou disponíveis para monocultura do eucalipto, sendo destinados às fabricas de papel e celulose. Sabe-se que essa área é bem maior, devido os plantios feitos também por produtores rurais. Toda essa área das empresas, utilizada pela monocultura do eucalipto na região, ao longo dos anos, teve a participação do Banco Nacional de Desenvolvimento Econômico e Social (BNDES) que, só no período de 2000 a 2011, investiu mais de R \$ 12,4 bilhões no setor (OBSERVATÓRIO SOCIAL, 2012).

Como consequência do dinamismo do setor, uma nova fusão aconteceu, em março de 2018. A Fibria Aracruz, líder mundial na produção de celulose de eucalipto, foi negociada pela segunda maior produtora de celulose de eucalipto do mundo, a Suzano Papel e Celulose. A nova companhia, resultado dessa fusão, criou a maior produtora de celulose do mundo (MERCADO, 2018).

Sob a ótica das frequentes transformações no setor de papel e celulose, aliadas aos incentivos do Estado e à necessidade constante de terras destinadas a atender ao setor, é que analisaremos os conflitos decorrentes da atividade florestal com as comunidades tradicionais que habitam as regiões pesquisadas. Infere-se que a introdução da monocultura do eucalipto, nas décadas de 1960 e 1970, como um novo componente agrícola, contribuiu para o desencadeamento de conflitos socioambientais entre as populações e as empresas do setor.

Apesar de a cadeia produtiva da celulose ter desempenhado um importante papel no equilíbrio das contas comerciais nacionais, ela apresenta fragilidades (ANDRADE; OLIVEIRA, 2016). Essas fragilidades são impactantes, principalmente, para as comunidades tradicionais locais. Cabe destacar que nessas regiões, além dos históricos incentivos financeiros e/ou fiscais do Estado para o cultivo de eucalipto, outras medidas foram tomadas, o que resultou na transformação desse território. Entre elas, estão os investimentos em infraestrutura, como a abertura da rodovia BR101, que liga Vitória ao sul da Bahia (ACSELRAD, 2007).

\section{POLÊM!CA $\mid$ LABORE}

Polêmica - Revista Eletrônica da Uerj - Rua São Francisco Xavier, 524, $1^{\circ}$ andar bloco D, sl.1001 • Tels.: +55 21 2334-4088 / 4087 • http://www.e-publicacoes.uerj.br/index.php/polemica/index http://www.labore.uerj.br • laboreuerj@yahoo.com.br 
A construção da rodovia BR101 foi um vetor de mudança que contribuiu para alterar o território em um movimento quase que sincronizado. As transformações foram, então, acontecendo: primeiro foram os madeireiros, cujo único objetivo era extrair a madeira, seguidos dos fazendeiros de gado. Isso provocou o empobrecimento e a desvalorização das propriedades na área de atuação desses atores, cenário ideal para concentração de terras e implantação das fábricas de papel e celulose ligadas à monocultura do eucalipto (ASCELRAD, 2007).

O norte do Espírito Santo e o sul da Bahia ofereciam outras vantagens para a monocultura do eucalipto, como: tempo reduzido de produção, graças às condições climáticas (média de sete anos); rendimento por área devido ao manejo das florestas; altos incentivos do BNDES, com financiamento a taxas de juros favoráveis; e, posteriormente, o melhoramento genético do eucalipto para região. Para completar, as empresas usaram o argumento da estagnação econômica das regiões, promovendo esperança de salvação e crescimento econômico. Assim, conseguiram o apoio político dos governos e dos empresários locais. Isso contribuiu para que houvesse, ali, uma multiplicação de cartórios, instrumento fundamental para captura de terras, por meio da grilagem, tanto de comunidades quilombolas e camponesas, quanto de aldeias indígenas (ASCELRAD, 2007; OBSERVATÓRIO SOCIAL, 2012).

Todos esses fatores contribuíram para implantação das fábricas do norte do Espírito Santo e do sul da Bahia e da monocultura do eucalipto. Nota-se que o setor de papel e celulose vem se adaptando às mudanças do mercado, no entanto, restam dúvidas sobre as ações que as empresas desenvolvem para resolver ou minimizar os conflitos ambientais provocados pela monocultura do eucalipto com as comunidades tradicionais que já habitavam as regiões.

\section{Conflitos ambientais e a monocultura do eucalipto}

A quantidade de área disponível para monocultura do eucalipto implica, diretamente, a expansão da produção do sertor de papel e celulose no Brasil. A demanda por terra e o próprio cultivo do eucalipto têm sido a causa dos conflitos ambientais. Em nove anos, a área de eucalipto aumentou 64,71\% em todo o País (IBÁ, 2016). Em 2016, a área de silvicultura no Brasil era de aproximadamente 7,8 milhões de hectares, dos quais 5,6 milhões eram de eucalipto e estavam distribuídos da seguinte forma, como apresentado na Figura 1.

\section{POLÊM!CA $\mid$ LABORË}

Polêmica - Revista Eletrônica da Uerj - Rua São Francisco Xavier, 524, $1^{\circ}$ andar bloco D, sl.1001 • Tels.: +55 21 2334-4088 / 4087 • http://www.e-publicacoes.uerj.br/index.php/polemica/index http://www.labore.uerj.br • laboreuerj@yahoo.com.br 
Figura - 1: Distribuição da área da monocultura do eucalipto no Brasil

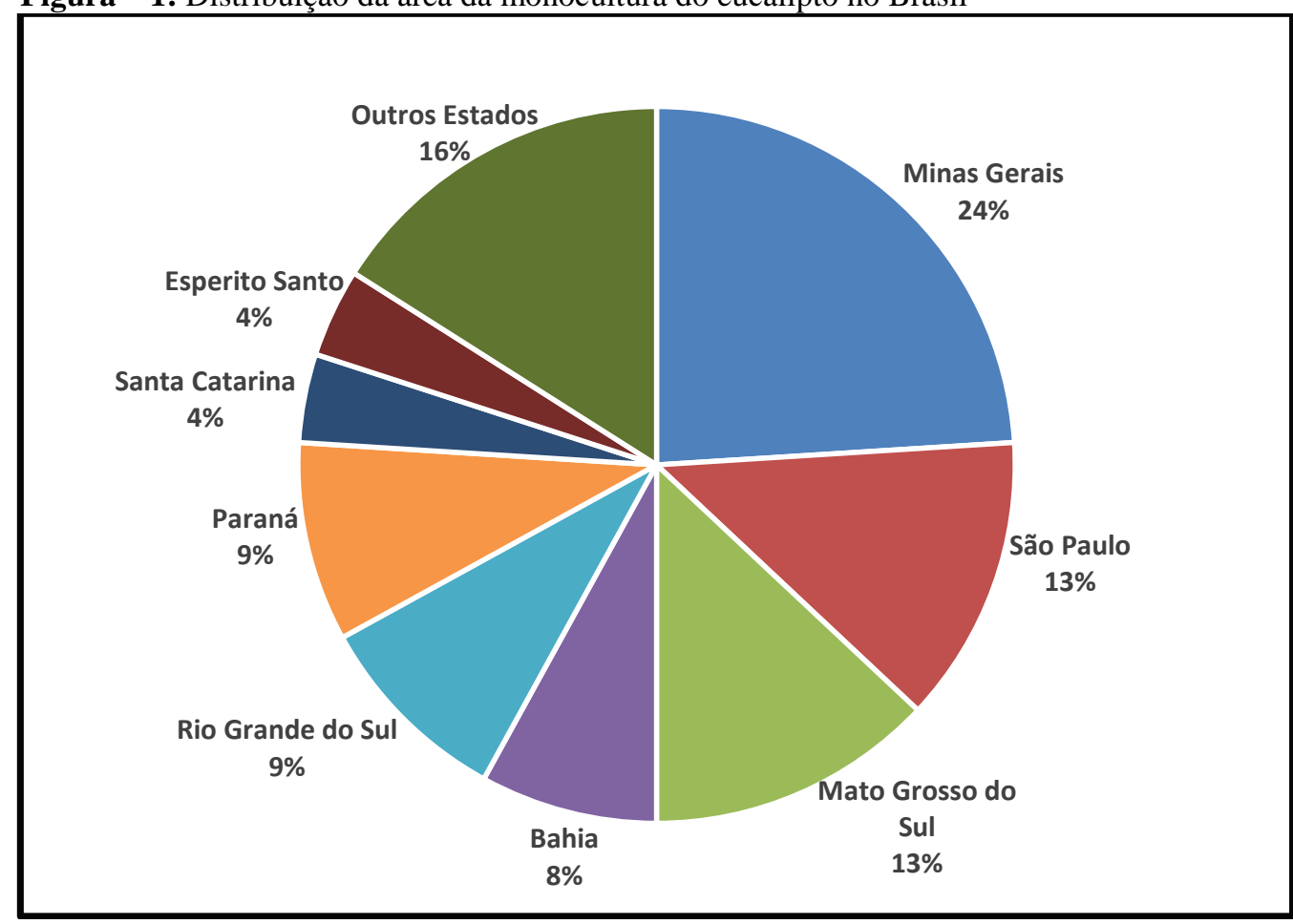

Fonte: adaptada do IBGE/SIDRA (2018).

A Figura 1 mostra que o Espírito Santo e a Bahia, onde estão instaladas as unidades da Fibria Aracruz, da Suzano Papel e Celulose e da Veracel Celulose, correspondem a 12\% da área total de eucalipto do País. Esse percentual, na sua maioria, é destinado ao setor de celulose, o que motiva a discutir os conflitos ambientais, com o olhar voltado para a monocultura do eucalipto nas duas regiões.

A situação da região compreendida entre o norte do Espírito Santo e o sul da Bahia, onde atuam as três referidas empresas do ramo de papel e celulose, apresenta-se delicada e merece atenção, pois para ampliar a produção as empresas precisam buscar novas terras para expansão da monocultura do eucalipto, e é nesse contexto que os conflitos ambientais surgem, como apresenta Muniz (2009). Segundo esse autor, eles acontecem "a partir da disputa pelo acesso aos bens e serviços ambientais, ou seja, são conflitos travados em torno dos problemas do uso e da apropriação dos recursos naturais" (2009, p. 181), no caso, a terra.

A busca incessante das empresas por aumento da produção, de novos mercados e da lucratividade tem gerado conflitos sociais e ambientais (SIMMEL, 1983). A interpretação desses conflitos depende de um enfoque interdisciplinar que consiga agregar elementos macro, micro e pessoais presentes na quase totalidade das situações conflituosas, o que acaba

\section{POLÊM!CA | LABORÉ}

Polêmica - Revista Eletrônica da Uerj - Rua São Francisco Xavier, 524, $1^{\circ}$ andar bloco D, sl.1001 • Tels.: +55 21 2334-4088 / 4087 • http://www.e-publicacoes.uerj.br/index.php/polemica/index http://www.labore.uerj.br • laboreuerj@yahoo.com.br 
dificultando o diálogo entre as empresas e as comunidades tradicionais. A cultura da empresa, seus objetivos e o mercado vão de encontro à cultura e aos interesses das comunidades onde essas empresas estão presentes, o que colabora para o surgimento e acirramento dos conflitos, com isso as ações que são definidas em nível de produção e exportação interferem nas regiões, nas comunidades e na vida das pessoas afetadas pela monocultura (BARBANTI JR., 2002).

Para Acselrad (2004) e Muniz (2009), o modelo de desenvolvimento econômico pode contribuir para os conflitos ambientais. Segundo os autores, esses conflitos são entendidos como a expressão de tensões na reprodução dos modelos de desenvolvimento que adotam práticas em que prevalece a lógica da apropriação privada dos bens e recursos comuns, o que leva a tensões e embates com as comunidades que necessitam desses bens e recursos. Alguns desses conflitos são relatados pelo Poder Judiciário, no Ministério Público da Bahia e no Ministério Público Federal, referentes a algumas empresas do setor de papel e celulose. Foram apontadas:

violações dos direitos humanos; lavagem de dinheiro; sonegação de impostos; corrupção; fraude na certificação ambiental $\mathrm{FSC}^{1}$; fraude em licenciamentos ambientais; terceirização ilícita de mão de obra; fraude em processos de arrendamento de terras; produção de documentos forjados; grilagem de terras; uso de policiais como vigilantes particulares; devastação de mata nativa; assoreamento de rios; ocupação ilegal de terras indígenas; ocupação ilegal de terras da União; ocupação ilegal de terras quilombolas (OBSERVATÓRIO SOCIAL, 2012, p. 10).

Os atores afetados pela implantação das monoculturas de eucalipto, como as comunidades tradicionais, as populações indígenas e os agricultores, manifestaram-se isoladamente, no início das plantações e durante a implantação das fábricas. Isso fez com que eles encontrassem dificuldade de reconhecimento, o que os levou a buscar o apoio de outros atores para se fortalecerem e legitimarem o movimento, como: organizações indígenas, comunidades quilombolas, movimento sociais, ONGs, entidades ambientais, dentre outras, que se manifestaram contra o modo como foi feita a expansão da monocultura do eucalipto nas regiões pesquisadas. No entanto, "os conflitos e as lutas travadas pelas comunidades por recursos ambientais são ao mesmo tempo lutas por sentidos culturais” (ACSELRAD, 2004, p. 19).

\footnotetext{
${ }^{1}$ O FSC (Forest Stewardship Council - Conselho de Manejo Florestal) é uma organização independente, não governamental, sem fins lucrativos, criada no início da década de 1990, com o intuito de contribuir para a promoção do manejo florestal responsável ao redor do mundo.
}

\section{POLÊM!CA $\mid$ LABORE}

Polêmica - Revista Eletrônica da Uerj - Rua São Francisco Xavier, 524, $1^{\circ}$ andar bloco D, sl.1001 • Tels.: +55 21 2334-4088 / 4087 • http://www.e-publicacoes.uerj.br/index.php/polemica/index http://www.labore.uerj.br • laboreuerj@yahoo.com.br 
O sentido cultural do meio ambiente é relatado por um índio atingido pela monocultura do eucalipto no norte do Espírito Santo:

\begin{abstract}
Meu nome é AC, sou índio Guarani, da aldeia Boa Esperança. Eu nasci na viagem em busca da Terra Sem Males, [...] Nós seguimos as leis da natureza, nós sentimos as coisas pelo coração e pela mente. A empresa de celulose está ferindo os nossos saberes. Para eles, as leis da natureza são invisíveis, eles não sentem a natureza, não sabem como respeitar a fauna e a flora. [...] O eucalipto traz tristeza e devastação (OBSERVATÓRIO SOCIAL, 2012, p. 43).
\end{abstract}

$\mathrm{O}$ depoimento de $\mathrm{AC}$ mostra o respeito dos índios pela terra e pela natureza, assim como evidencia o conflito existente entre os indígenas e as empresas de celulose. A fala de AC apresenta o espaço simbólico onde se desenvolvem os conflitos ambientais evocados para legitimar acordos e regular os conflitos que envolvem a percepção de natureza e de meio ambiente (ACSELRAD, 2004).

Nas regiões do norte do Espírito Santo e sul da Bahia, são observados conflitos entre as comunidades tradicionais e indígenas e os interesses privados das grandes empresas de celulose que exploram a monocultura do eucalipto. Essas regiões são povoadas por aproximadamente 34 comunidades quilombolas e pelos índios Tupinikins. Uma das fábrica de papel e celulose, localizada na cidade de Aracruz/ES, foi construída onde seria a antiga aldeia dos índios Tupinikins (ACSELRAD, 2007).

Para os quilombolas, a chegada das empresas foi claramente percebida quando essas compraram as terras em volta das comunidades. O depoimento dos moradores dessas comunidades, dado ao Observatório Social (2012), permite analisar a dimensão dos conflitos instaurados nas regiões afetadas.

Para convencer os quilombolas a abandonar a terra, uma das empresas tinha um método dividido em duas fases. Na primeira, as comunidades eram visitadas por um negro chamado PL, ligado ao movimento quilombola, que tentava convencer as famílias a vender as terras. Para isso, usava de variadas artimanhas. A principal delas era convencer os membros da comunidade, sem documentação, que era melhor vender a terra. Segundo PL, a empresa teria poder para tirar todo mundo da terra. Caso a ação de PL falhasse, iniciava-se a segunda fase, quando entrava em ação o tenente MT, oficial da ativa do Exército, que usava o seguinte argumento: "ou sai por bem ou por mal" (OBSERVATÓRIO SOCIAL, 2012).

O uso dessa estratégia pode ser confirmado no relato de uma moradora das comunidades quilombolas afetadas:

\title{
POLÊM!CA $\mid$ LABORE
}

Polêmica - Revista Eletrônica da Uerj - Rua São Francisco Xavier, 524, $1^{\circ}$ andar bloco D, sl.1001 • Tels.: +55 21 2334-4088 / 4087 • http://www.e-publicacoes.uerj.br/index.php/polemica/index http://www.labore.uerj.br • laboreuerj@yahoo.com.br 


\begin{abstract}
Meu nome é LS, moro em São Domingos, uma comunidade quilombola localizada no norte do Espírito Santo. Sou prima-irmã de PL, o homem contratado pela empresa para convencer o nosso povo a entregar as terras. Estamos inviabilizados economicamente. Não temos mais terra para trabalhar. Estamos cercados pelos eucaliptos e vivemos de cesta básica e de bolsa família. Não é o que queremos. O que queremos é nosso território. Somos trabalhadores rurais, nossos ancestrais chegaram aqui há mais de 150 anos [...], estamos sendo dizimados como cultura, como povo, como nação. Estamos sendo riscados do mapa, sufocados pela ação criminosa de grupos econômicos que atuam sob a simpatia e o estímulo do governo brasileiro (OBSERVATÓRIO SOCIAL, 2012, p. 15).
\end{abstract}

O caso dos indígenas não foi muito diferente das comunidades quilombolas. Eles ficaram espremidos em $0,1 \%$ do seu território original e enfrentaram uma guerra aberta contra as empresas de papel e celulose. As empresas alegavam que os indígenas não eram indígenas e que a terra onde tinham suas aldeias pertencia a elas (OBSERVATÓRIO SOCIAL, 2012).

Todo esse processo de convencimento e compra de terras levou várias famílias a se mudarem para a cidade. O baixo valor pago pelas terras impossibilitou as famílias de reconstruírem suas vidas em locais apropriados, portanto, muitas delas se viram obrigadas a ir para as periferias das cidades, gerando, assim, outros problemas sociais e ambientais (ACSELRAD, 2004).

Cabe destacar que esse fenômeno de expulsão da população rural não é algo novo no Brasil. E vale a pena ressaltar que as transformações da agricultura, a concentração fundiária e a industrialização contribuíram para que milhares de brasileiros deixassem o campo rumo às cidades, ao longo dos processos de transformação do rural e das atividades agrícolas (WANDERLEY, 2000). Esse processo de migração pode transformar a estrutura da sociedade brasileira, nos aspectos demográficos, econômicos e sociais.

\title{
Comunidades tradicionais do Espírito Santo e da Bahia e conflitos com a monocultura do eucalipto
}

Depois das discussões sobre os conflitos ambientais e a monocultura do eucalipto, busca-se entender os atores desse processo, por meio de um debate sobre as populações tradicionais no Brasil. Diversos autores vêm tentando conceituar populações, povos e/ou comunidades tradicionais. No geral, as análises giram em torno das formas de uso e apropriação do território, dos recursos naturais e das territorialidades específicas, como no caso de populações extrativistas, quilombolas e indígenas (DIEGUES, 2008; BRANDÃO; BORGES, 2014). O Estado, por meio do Decreto $n^{-}$6.040, de 7 de fevereiro de 2007, instituiu a Política

\section{POLÊM!CA $\mid$ LABORE}

Polêmica - Revista Eletrônica da Uerj - Rua São Francisco Xavier, 524, $1^{\circ}$ andar bloco D, sl.1001 • Tels.: +55 21 2334-4088 / 4087 • http://www.e-publicacoes.uerj.br/index.php/polemica/index http://www.labore.uerj.br • laboreuerj@yahoo.com.br 
Nacional de Desenvolvimento Sustentável dos Povos e Comunidades Tradicionais, que também traz elementos que contribuem para conceituar essas populações (BRASIL, 2007).

Dentro de uma perspectiva marxista, "as culturas tradicionais estão associadas a modos de produção pré-capitalista, próprios de sociedades em que o trabalho ainda não se tornou mercadoria, onde há grande dependência dos recursos naturais e dos ciclos da natureza" (DIEGUES, 2008, p. 84). Outro olhar conceitua as comunidades tradicionais, baseando-se em uma linha do tempo, ou seja, comunidades tradicionais são aquelas que ali estavam quando outros grupos humanos, populares ou não, chegaram e se estabeleceram. Essas comunidades mantêm uma forte relação com o território e são importantes protagonistas na resistência e luta pela preservação dos seus recursos naturais, materiais e culturais (BRANDÃO; BORGES, 2014).

A Diretiva Operacional no 4.20, de 1991, do Banco Mundial, construiu a base da classificação dos povos indígenas, destacando que eles apresentam fortes ligações com os territórios de seus ancestrais, autoidentificação, linguagem própria e instituições sociais e políticas próprias e tradicionais, com um sistema de produção voltado para subsistência dos membros da aldeia (DIEGUES, 2008).

As comunidades rurais negras, que normalmente são originadas de descendentes diretos de trabalhadores escravizados, são classificadas como comunidades quilombolas, reconhecidas pela Constituição Federal brasileira em 1988, que em tese deveria garantir o direito sobre a terra e os recursos naturais dos territórios que essas comunidades ocupam, há gerações. No entanto, o que se percebe é que as lutas pela garantia desses direitos, os conflitos pela posse do território e a manutenção de sua cultura estão mais vivos do que nunca (DIEGUES et al., 2000).

Os quilombolas têm uma cultura e uma história particular, marcadas pela influência negra, não só nas atividades agrícolas e no uso dos recursos naturais, mas também nas questões culturais. Essa definição é comprovada pelo depoimento de uma moradora de um dos quilombos afetados pela monocultura do eucalipto:

Meu nome é EJ. Moro com minha família na comunidade São Jorge no Espírito Santo. Todos aqui são descendentes do velho Valentim, meu bisavô, escravo fugido das fazendas de mandioca, do tempo da escravatura. Eu moro aqui desde que me entendo por gente. Posso dizer com certeza que essa terra aqui é nossa, porque eu nasci aqui e minha mãe também nasceu aqui. Toda essa terra coberta de eucalipto é nossa. $\mathrm{O}$ meu povo plantava abóbora, milho, mandioca. Isso aqui era moradia de negro quilombola, gente fugida da escravidão e gente liberta que ganhou terra (OBSERVATÓRIO SOCIAL, 2012, p. 10).

\section{POLÊM!CA $\mid$ LABORE}

Polêmica - Revista Eletrônica da Uerj - Rua São Francisco Xavier, 524, $1^{\circ}$ andar bloco D, sl.1001 • Tels.: +55 21 2334-4088 / 4087 • http://www.e-publicacoes.uerj.br/index.php/polemica/index http://www.labore.uerj.br • laboreuerj@yahoo.com.br 
A fala corrobora as definições apresentadas (DIEGUES, 2008; PEREIRA; DIEGUES, 2010; BRANDÃO; BORGES, 2014). A forte relação com a terra e os conflitos existentes também podem ser analisados no depoimento de EJ.

\begin{abstract}
Tinha muita floresta aqui até as máquinas da firma chegarem com o correntão, que derrubou tudo, até nossas plantações. Perdi meu irmão, meu sobrinho e perdi meu próprio filho. Meu filho tinha 7 anos. Morreu depois de vomitar sangue durante uma semana. Ele comeu uma castanha contaminada pelo Roundup, o veneno que a empresa de celulose aplicava sobre o eucalipto [...]. A firma quer que a gente vá embora, mas nós vamos ficar, essa terra tá lavada com o nosso sangue. Essa terra é sagrada (OBSERVATÓRIO SOCIAL, 2012, p. 11).
\end{abstract}

Dentre os elementos encontrados nesses estudos, cabe destacar que, em algumas situações, essas populações sofreram um conjunto de violências, entre elas uma violência simbólica, como no caso dos indígenas, que para conseguirem trabalho precisavam abdicar de sua própria identidade. Já nas comunidades quilombolas, além da perda do território, muitos se viram forçados a vender suas terras por preços inferiores aos do mercado e a migrar para os centros urbanos. A falta de qualificação e de formação acadêmica impactou diretamente a qualidade de vida desses grupos. Destacam-se aqueles que resistiram, não venderam suas terras e ficaram para lutar pelos seus direitos (ACSELRAD, 2007).

A estratégia de cooptação das lideranças impactava as comunidades de duas formas: primeiro, enfraquecia a resistência e, segundo, gerava desconforto e conflito entre os membros dessas comunidades, o que favorecia a negociação de forma individual, produzindo excelentes resultados para as empresas do setor de papel e celulose, uma vez que dividia as comunidades e facilitava as negociações.

Cabe destacar que as estratégias utilizadas pelas empresas, no final do século XX, cujo objetivo era a expansão da área plantada, não impediram o início de um movimento de resistência, reunindo, além dos quilombolas, outros atores sociais, como: índios Guaranis e Tupinikins, carvoeiros, estudantes, professores, advogados, assessores parlamentares e ONGs, formando, naquele momento, uma rede de alerta ao deserto verde, que mais tarde deu origem à Rede Deserto Verde.

Esse movimento logo se estendeu para a Bahia e, em 2002, esse grupo se articulou no estado de Minas Gerais contra a expansão da monocultura do eucalipto. Suas reivindicações foram marcadas por mobilizações, manifestações, marchas, ocupações, pressões, cartas abertas, encontros, publicações, fillmes, audiências públicas, presença em CPIs legislativas, disputas em

\title{
POLÊM!CA $\mid$ LABORE
}

Polêmica - Revista Eletrônica da Uerj - Rua São Francisco Xavier, 524, $1^{\circ}$ andar bloco D, sl.1001 • Tels.: +55 21 2334-4088 / 4087 • http://www.e-publicacoes.uerj.br/index.php/polemica/index http://www.labore.uerj.br • laboreuerj@yahoo.com.br 
torno do licenciamento, certificação de plantios e de crédito de carbono, denúncia em rede e em fóruns internacionais, processos e ações civis, dentre outras ações, como a publicação do documento produzido pelo Observatório Social de 2012.

Essas mobilizações têm provocado mudanças. O Estado e as empresas do setor de papel e celulose passaram a reconhecer essas comunidades como atores legítimos no processo de reivindicação de terras. Porém, com "a omissão governamental, as empresas fazem o que querem. Avançam sobre os últimos focos de resistência e exercem pressão direta sobre as comunidades, as quais estão cercadas pelos eucaliptos e, assim, inviabilizadas economicamente" (OBSERVATÓRIO SOCIAL, 2012, p. 21). São pequenas comunidades altamente fragilizadas do ponto de vista dos direitos humanos, da segurança alimentar e do acesso à terra.

A priori, o reconhecimento da resistência desse movimento diante das comunidades onde estão inseridas tem proporcionado resultados. Mas, em contrapartida, as empresas têm usado um conjunto de estratégias com o intuito de enfraquecer o movimento, dentre as quais é possível citar a ameaça de redução de investimento e diminuição de empregos, além da ameaça de se deslocarem para outras regiões. Esse deslocamento gera consequências econômicas locais que, por sua vez, interferem negativamente na opinião pública sobre as ações do movimento contra as empresas (ACSELRAD, 2007).

O Brasil ocupa o terceiro lugar no ranking de conflitos ambientais. A atividade das empresas do setor de papel e celulose dessas regiões impactam diretamente os modos de vida das populações indígenas e quilombolas, dos pescadores e até dos trabalhadores rurais, na medida em que ocasionam a perda da terra, de florestas, de água e de oportunidade de trabalho, e acrescenta que essas comunidades vivem cercadas pelo eucalipto, o que caracteriza claramente um conflito ambiental (BBC BRASIL, 2014).

O mapa mundial de conflitos ambientais apontou que, no norte do Espírito Santo, milhares de hectares estão se transformando em deserto verde, por causa da monocultura de eucalipto. Esse deserto verde pode ser interpretado na fala de uma moradora das comunidades quilombolas, ao dizer que

Do lado de fora, não havia nada além de um silêncio seco e pesado, quebrado às vezes pelo vento, que fazia estremecer as copas mais altas do mar de eucaliptos que agora cercava a Vila São Jorge. Um mar verde, uniforme, sem pássaros, sem animais, sem os tratores que anos atrás colocaram abaixo 150 anos de trabalho duro, iniciado pelo

\section{POLÊM!CA $\mid$ LABORE}

Polêmica - Revista Eletrônica da Uerj - Rua São Francisco Xavier, 524, $1^{\circ}$ andar bloco D, sl.1001 • Tels.: +55 21 2334-4088 / 4087 • http://www.e-publicacoes.uerj.br/index.php/polemica/index http://www.labore.uerj.br • laboreuerj@yahoo.com.br 
bisavô Valentim, escravo fugido das fazendas que cobriam a região no Século 19 (OBSERVATÓRIO SOCIAL, 2012, p. 21).

Os inúmeros depoimentos apresentados pelo Observatório Social e as pesquisas feitas por Henri Acselrad retratam as faces do conflito ambiental provocado pela monocultura do eucalipto, utilizada como matéria-prima para alimentar o setor de papel e celulose instalado nos dois estados.

O sofrimento, as angústias e as lutas das comunidades tradicionais contra a monocultura do eucalipto e as empresas de papel e celulose demonstram que a situação deve ser cuidadosamente tratada pelas empresas e pelo poder público. A perda dessas comunidades não é só econômica, os danos se refletem nas questões sociais, culturais e, principalmente, ambientais.

A pauperização dessas populações tradicionais como fruto desse processo é, muitas vezes, a miséria extrema que, associada à perda de direitos históricos sobre áreas em que viviam, tem levado muitas comunidades de moradores a sobre-explorar os recursos naturais (DIEGUES, 2008). As condições de miséria extrema acabam levando a um ciclo vicioso, pois como apontado pela Comissão Mundial sobre o Meio Ambiente e Desenvolvimento "a própria pobreza polui o meio ambiente, criando outro tipo de desgaste ambiental. Para sobreviver os pobres muitas vezes destroem seu próprio meio ambiente [...]. O feito cumulativo dessas mudanças chega a fazer com que a própria pobreza seja um dos maiores flagelos do mundo" (CMED, 1991, p. 30).

\section{Considerações finais}

As implicações da monocultura do eucalipto no norte do Espírito Santo e no sul da Bahia estão diretamente ligadas a uma assimetria de força, na qual os membros dessas comunidades são marginalizados e levados à pobreza extrema, o que pode resultar em um inchaço das periferias das cidades. Para os que permanecem nas comunidades, além do sofrimento, da falta de emprego e da eliminação da biodiversidade florestal, ainda continua sobre eles a pressão das empresas de papel e celulose, que querem suas terras para expandir as plantações de eucalipto.

Apesar de Lopes e Oliveira (2018, p. 48) destacarem que "os movimentos sociais e as populações tradicionais e indígenas foram relegados a segundo plano e não apareceram nos debates sobre os direitos aos territórios e direitos básicos de reprodução de seus modos de vida", o que se observa na realidade é que os conflitos dessas comunidades com a monocultura de

\section{POLÊM!CA $\mid$ LABORE}

Polêmica - Revista Eletrônica da Uerj - Rua São Francisco Xavier, 524, $1^{\circ}$ andar

bloco D, sl.1001 • Tels.: +55 21 2334-4088 / 4087 • http://www.e-publicacoes.uerj.br/index.php/polemica/index http://www.labore.uerj.br • laboreuerj@yahoo.com.br 
eucalipto têm levado as pessoas a se organizarem e desenvolverem uma série de estratégias que possibilitem resistir a essa realidade. Mesmo com a falta de apoio do Estado, as comunidades, os movimentos sociais e outras instituições lutam insistentemente pelo reconhecimento dos seus direitos e pela criação de políticas que protejam seus membros.

Outro ponto importante é o uso excessivo da terra para monocultura do eucalipto, o que pode transformar o norte do Espírito Santo e o sul da Bahia em um deserto, devido à deterioração do meio ambiente, levando muito mais pobreza a uma região que foi rica em recursos naturais.

Além dos conflitos com a monocultura do eucalipto, existem os conflitos pela forma com que as empresas de celulose no norte do Espírito Santo e no sul da Bahia, analisadas por Henri Acselrad e pelo Observatório Social, se apropriaram das terras das comunidades quilombolas e indígenas. A solução desses conflitos só será possível com o apoio do poder público e com a mobilização política dessas comunidades.

Por outro lado, reconhece-se a importância do setor de celulose para a economia brasileira, o que justifica a participação do Estado nas atividades ligadas ao setor de papel e celulose. O Estado, por apresentar interesse no desenvolvimento do setor, também precisa se posicionar ativamente para resolução dos conflitos, uma vez que a expansão da indústria de celulose e da atividade florestal foi estimulada para o crescimento econômico. Os resultados econômicos do setor de papel e celulose também podem ser direcionados legalmente para minimizar os impactos gerados pela monocultura do eucalipto.

Dados dos municípios onde as empresa de celulose desenvolvem atividade florestal mostram a importância de se monitorar o avanço da monocultura sobre as áreas de Mata Atlântica, um vez que essas apresentam percentuais baixos em relação à extensão do município. Em determinados lugares, mais de $40 \%$ do município é de floresta plantada.

A fusão das empresas Fibria Aracruz e Suzano Papel e Celulose, em março de 2018, envolve várias unidades no Brasil e, em especial, as unidades do Espírito Santo e da Bahia. A empresa resultante dessa fusão necessita de atenção especial, pois as empresas agora fazem parte de um único grupo, o que pode facilitar a solução dos conflitos existentes, ou intensificar e criar novos conflitos com as comunidades quilombolas e indígenas que habitam as regiões.

Como sugestão para futuros trabalhos, aponta-se a necessidade de um recenseamento das áreas e das comunidades afetadas pela monocultura do eucalipto. Faz-se necessário,

\section{POLÊM!CA $\mid$ LABORE}

Polêmica - Revista Eletrônica da Uerj - Rua São Francisco Xavier, 524, $1^{\circ}$ andar bloco D, sl.1001 • Tels.: +55 21 2334-4088 / 4087 • http://www.e-publicacoes.uerj.br/index.php/polemica/index http://www.labore.uerj.br • laboreuerj@yahoo.com.br 
também, políticas públicas direcionadas às comunidades afetadas pela atividade florestal das indústrias de celulose, bem como para minimizar os impactos da monocultura sobre a Mata Atlântica.

\section{Referências}

ACSELRAD, Henri (Org.). Conflitos ambientais no Brasil. Rio de Janeiro: Fundação Heinrich Böll: Relume Dumará, 2004.

ACSELRAD, Henri. O movimento de resistência à monocultura do eucalipto no norte do Espírito Santo e extremo sul da Bahia - uma sociologia da recusa e do consentimento em contexto de conflito ambiental. In: CONGRESSO BRASILEIRO DE SOCIOLOGIA DA UFPE, 13., 2007. Recife. Anais... Recife: SBS, 2007. Disponível em: http://www.sbsociologia.com.br/portal/index.php?option=com_docman\&task=cat_view\&gid=47\&Itemid=171 . Acesso em: 28 out. 2017.

ANDRADE, Maicon L.; OLIVERIA, Gilca, G. de. A monocultura do eucalipto na Bahia: um retrato da apropriação privada da natureza. Cadernos do CEAS, Salvador, n. 237, p. 294-326, 2016. Disponível em: https://cadernosdoceas.ucsal.br/index.php/cadernosdoceas/article/view/249. Acesso em: 16 out. 2017.

BARBANTI JR., Olympio. Conflitos socioambientais: teorias e práticas. In: ENCONTRO DA ASSOCIAÇÃO NACIONAL DE PÓS-GRADUAÇÃO E PESQUISA EM AMBIENTE E SOCIEDADE (ANPPAS), 1., 2002, Indaiatuba. Anais... Indaiatuba: ANPPAS, 2002. Disponível em: http://www.anppas.org.br/encontro_anual/encontro2/GT/GT17/gt17_little.pdf. Acesso em: 01 out. 2017.

BBC BRASIL. Mapa inédito coloca o Brasil em 3o lugar em conflitos ambientais. São Paulo, 21 mar. 2014 , Disponível em: http://www.bbc.com/portuguese/noticias/2014/03/140321_disputas_ambientais_mdb. Acesso em: 07 set. 2017.

BRANDÃO, Carlos R.; BORGES, Maristela Correira. O lugar da vida - Comunidade e Comunidade Tradicional / El lugar de la vida - Comunidad y Comunidad Tradicional. Campo - Território: Revista de Geografia Agrária, v. 9, n. 18, 11 jul. 2014.

BRASIL. Decreto no 6.040, de 7 de fevereiro de 2007. Institui a Política Nacional de Desenvolvimento Sustentável dos Povos e Comunidades Tradicionais. Diário Oficial da União, Rio de Janeiro, 8 fev. 2007. Disponível em: http://www.planalto.gov.br/ccivil_03/_ato2007-2010/2007/decreto/d6040.htm. Acesso em: 26 jul. 2018.

CAMACHO, Rodrigo Simão. A insustentabilidade social e ambiental do agronegócio: A territorilização do complexo celulose-papel na região leste de Mato Grosso do Sul. Revista Científica ANAP Brasil, v. 5, n. 6, dez. 2012. DOI: http://dx.doi.org/10.17271/19843240562012401.

CMED - COMISSÃO MUNDIAL SOBRE O MEIO AMBIENTE E DESENVOLVIMENTO. Preocupações Comuns. In: COMISSÃO MUNDIAL SOBRE O MEIO AMBIENTE E DESENVOLVIMENTO. Nosso Futuro Comum. 2. ed. Rio de Janeiro: Fundação Getúlio Vargas, 1991. p. 1-71.

DIEGUES, Antônio Carlos (Org.). Os saberes tradicionais e a biodiversidade no Brasil. Brasília: MMA: São Paulo: MMA/COBIO/NUPAUB/USP, 2000. p. 1-71.

DIEGUES, Antônio Carlos. O mito moderno da natureza intocada. 6. ed. Ampliada. São Paulo: Hucitec: Nupaub-USP/CEC, 2008. p. 77-103.

\section{POLÊM!CA $\mid$ LABORE}

Polêmica - Revista Eletrônica da Uerj - Rua São Francisco Xavier, 524, $1^{\circ}$ andar bloco D, sl.1001 • Tels.: +55 21 2334-4088 / 4087 • http://www.e-publicacoes.uerj.br/index.php/polemica/index http://www.labore.uerj.br • laboreuerj@yahoo.com.br 
FERNANDES, Bernardo Mançano. Questão agrária: conflitualidade e desenvolvimento territorial. In: BUAINAIN, Antônio M. (Ed). Luta pela terra, reforma agrária e gestão de conflitos no Brasil. Campinas: Unicamp, 2005.

FIBRIA. Resumo Público do Plano de Manejo Florestal 2017 - Unidade Aracruz. Aracruz, ES: CERFLOR, 2017. Relatório. Disponível em: http://www.fibria.com.br/wpcontent/uploads/2017/11/resumo_versao_EMAIL.pdf. Acesso em: 02 mar. 2018.

GERMANI, Guiomar Inez. Condições históricas e sociais que regulam o acesso a terra no espaço agrário brasileiro. GeoTextos, v. 2, n. 2, p. 115-147, 2006. DOI: http://dx.doi.org/10.9771/1984-5537geo.v2i2.3040.

IBGE. Sistema IBGE de Recuperação Automática - SIDRA. Disponível em: http://www.sidra.gov.br/bda/tabela/listabl.asp. Acesso em: 26 abr. 2018.

IBÁ - INDÚSTRIA BRASILEIRA DE ÁRVORES. Relatório anual do IBÁ - 2016. São Paulo, 2016.

KAGEYAMA, Ângela (Coord). O novo padrão agrícola brasileiro: do complexo rural aos complexos agroindustriais. In: DELGADO, G. et al. (Org). Agricultura e políticas públicas. Brasília: IPEA, 1990. p. 113123.

LITTLE, Paul E. A etnografia dos conflitos socioambientais: bases metodológicas e empíricas. In: ENCONTRO DA ASSOCIAÇÃO NACIONAL DE PÓS-GRADUAÇÃO E PESQUISA EM AMBIENTE E SOCIEDADE (ANPPAS), 1., 2004. Indaiatuba. Anais... Indaiatuba: ANPPAS, 2004. Disponível em: http://www.anppas.org.br/encontro_anual/encontro2/GT/GT17/gt17_little.pdf. Acesso em: 06 jan. 2018.

LOPES, Virginia Maria Canônico; OLIVERIA, Marcelo Leles Romarco de. O novo marco legal para mineração e suas implicações para a atividade minerária no Brasil sob a luz da justiça ambiental. Polêm!ca, Rio de Janeiro, v. 18, n. 3, p. 33-53, jul./set. 2018. DOI: https://doi.org/10.12957/polemica.2018.39422.

MAPBIOMAS. Projeto MapBiomas - Coleção 4.0 da Série Anual de Mapas de Cobertura e Uso de Solo do Brasil, Disponível em: http://plataforma.mapbiomas.org/. Acesso em: 30 mar. 2019.

MARTINS, José de Souza. O cativeiro da terra. São Paulo: Hucitec, 2004.

MERCADO. Jornal a Folha de São Paulo. São Paulo, 16 mar. 2018. Disponível em: https://www1.folha.uol.com.br/mercado/2018/03/acoes-da-suzano-disparam-e-as-da-fibria-despencam-aposfusao.shtml. Acesso em: 10 abr. 2018.

MUNIZ, Lenir Moraes. Ecologia política: O campo de estudo dos conflitos sócio-ambientais. Revista PósCiências Sociais, v. 6, n. 12, p.181-195, 2009.

OBSERVATÓRIO SOCIAL. O falso verde. Revista Observatório Social. Edição especial 15 anos, São Paulo, 2012.

OLIVEIRA, A. U. de. A Mundialização da Agricultura Brasileira. In: XII COLÓQUIO INTERNACIONAL DE GEOCRÍTICA, 12, 2012, Bogotá. Actas. Barcelona: Geocrítica, 2012. V. 1, p. 1-15

PEREIRA, Bárbara E.; DIEGUES, Antonio Carlos. O conhecimento de populações tradicionais como possibilidade de conservação da natureza: uma reflexão sobre a perspectiva da etnoconservação.

Desenvolvimento e Meio Ambiente. n. 22, p. 37-50, jul./dez. 2010. DOI: http://dx.doi.org/10.5380/dma.v22i0.1605.

ROSA, Marcos Reis. Comparaçao e analise de diferentes metodologias de mapeamento da cobertura florestal da Mata Atlantica. Boletim Paulista de Geografia, v. 95, p. 25-34, 2016.

\section{POLÊM!CA $\mid$ LABORE}

Polêmica - Revista Eletrônica da Uerj - Rua São Francisco Xavier, 524, $1^{\circ}$ andar bloco D, sl.1001 • Tels.: +55 21 2334-4088 / 4087 • http://www.e-publicacoes.uerj.br/index.php/polemica/index http://www.labore.uerj.br • laboreuerj@yahoo.com.br 
SCOTTO, Gabriela (Coord.). Conflitos ambientais no Brasil: natureza para todos ou somente para alguns? Rio de Janeiro: IBASE/Fundaçao Heinrich Boll, 1997.

SIMMEL, Georg. Sociologia. In: MORAES FILHO, Evaristo (Org.) Simmel. São Paulo: Ática, 1983. p. 122164.

STÉDILE, João Pedro (Org.); ESTEVAM, Douglas. A questão agrária do Brasil: debate sobre a situação e perspectivas da reforma agrária na década de 2000. São Paulo: Expressão Popular, 2013. V. 8.

SUZANO, Resumo público do Plano de Manejo Florestal 2013 - Unidade Florestal Bahia. São Paulo, SP, 2013. Relatório. Disponível em: http://www.suzano.com.br/wpcontent/uploads/2016/10/sumario_2013ba_corrigido_parte1-1.pdf. Acesso em: 06 abr. 2018.

VERACEL. Resumo Plano de Manejo Florestal Integrado 2016. Eunápolis, 2016. Relatório. Disponível em: http://www.veracel.com.br/wp-content/uploads/2017/10/Resumo-do-Plano-de-Manejo-Integrado-

2016_V2_Baixa.pdf. Acesso em: 12 fev. 2018.

WANDERLEY, Maria de N. B. A emergência de uma nova ruralidade nas sociedades modernas avançadas - o "rural" como espaço singular e ator coletivo. Estudos Sociedade e Agricultura, v. 8, n. 2, 2000. Disponível em: https://revistaesa.com/ojs/index.php/esa/article/view/178. Acesso em: 10 jun. 2018.

Recebido em: 27/02/2019.

Aceito em: 30/03/2019.

\section{POLÊM!CA $\mid$ LABORE}

Polêmica - Revista Eletrônica da Uerj - Rua São Francisco Xavier, 524, $1^{\circ}$ andar bloco D, sl.1001 • Tels.: +55 21 2334-4088 / 4087 • http://www.e-publicacoes.uerj.br/index.php/polemica/index http://www.labore.uerj.br • laboreuerj@yahoo.com.br 